\title{
Problems Arising from Talak Divorce Outside the Court
}

\author{
Ilham Hidayat; Yaswirman; Mardenis
}

Faculty of Law, Andalas University, Padang, Indonesia

http://dx.doi.org/10.18415/ijmmu.v6i10.919

\begin{abstract}
The birth of the Marriage Law No. 1 of 1974, especially the breakup of marriage has led to the dualism of Islamic law in Indonesia. Regarding Divorce on the one hand, Muslims are taught in Islamic fiqh that Divorce is the right of a husband, where if a wife is mentally ill even without a witness, then the divorce falls, while the marriage law in Indonesia, including the Islamic ummah, is specifically regulated in the Law Compilation Islam, determines that divorce can only be done before a religious court after going through a trial. Moreover, two Islamic organizations in Indonesia, namely Muhammadyah and Nahdlatul Ulama have different opinions. On the one hand, NU in the 28th Congress in Yogyakarta in 1989 gave a legal decision that Divorce was the husband's prerogative which could be dropped anytime and anywhere even without reason. If the husband has dropped divorce outside the Religious Court, then the divorce is valid. While the Majlis Tarjih Muhammadiyah in his fatwa that was tried on Friday, 8 Jumadal Ula 1428 H / 25 May 2007 M gave a ruling that divorce must be carried out through a court examination process, divorce carried out outside the court was declared invalid. The views of NU and Muhammadiyah above reflect a contradiction. Therefore the Indonesian Ulema Council based on the MUI IV 2012 Fatwa gave a fatwa as a middle way to resolve these differences with its fatwa that divorce outside the legal court is valid provided there is a syar'i reason that the truth can be proven in court. Iddah Divorce is calculated since husband drops divorce and for the benefit of benefit and guarantees legal certainty, divorce outside the court must be reported (ikhbar) to the religious court. With the Normative Juridical research method, the author tries to discuss the problem, namely trying to find the problems that arise as a result of these rules and find a way out how the MUI fatwa can be applied. From the results of the study, the authors conclude that the unrecognized Divorce legality outside the court causes legal chaos due to uncertain laws for the Islamic ummah, namely in terms of when the fall of divorce and the end of the iddah period, concerning triple divorce, concerning the validity of the status of children born after the fall Divorce and concerning the validity of the second marriage and the status of the child that was born which could damage the religion and descent of the Islamic ummah in Indonesia. If Marriage is legal according to the religion, then Divorce should also be valid if carried out according to the religious law. Factors that cause divorce outside the court include economic factors, juridical factors, sociological factors and customs factors, regarding the distribution of marital assets due to divorce outside the court, in general, the community resolves issues regarding marital property in a family manner by including local ulama and traditional leaders.
\end{abstract}

Keywords: Talak Divorce; Majelis Ulama Indonesian 


\section{Introduction}

Allah implies marriage and is made a strong foundation for human life because of some high values and some main goals that are good for humans to achieve a happy life and stay away from inequality and irregularities . The purpose of marriage according to Law No. 1 of 1974 forms a happy and eternal family. Article 1 emphasizes: "Marriage is an inner and outer bond between a man and a woman as husband and wife with the aim of forming a happy and eternal family based on the One Godhead . So marriage is a religious engagement because the legal effect is to bind men and women in an inner and outer bond as husband and wife so marriage not only has an element of lahiriyah but also an inner element.

Then, viewed from the aspect of marital law, it is an agreement as stated in Al-quran letter An Nisa '(4): 2, which is essentially marriage is a "very strong agreement", which is called the term "miistaaqan ghaliizhan" . In addition, as an excuse to state that the marriage is an agreement because of: first, the way to enter into a marriage bond has been arranged in advance, namely with a marriage contract and harmony and a certain contract. Second, the way to decipher or break the marriage bond has also been arranged beforehand, namely by the procedure of divorce, the possibility of fasakh, syiqaq, and so on.

From the meaning of the marriage, marriage is not only synonymous with parties and honeymoon, but an effort to blend the soul between two people who have become husband and wife. But in reality to build a happy marriage is not easy, often marriage life runs aground in the middle of the road. It's not happiness or calm that is obtained in the household, but what often happens is a fight. So that living together no longer brings peace and happiness, on the contrary it is always bickering, causing suffering and misery. Therefore, Islam, in addition to ordering to maintain marital permanence, also paves the way to get out of household problems that cannot be resolved by giving space for divorce, if indeed there is no other solution. This divorce is a small opportunity, which will only be used in desperate need, when indeed all the ways to save marriage are closed.

In Islamic law, divorce is called talak, meaning to let go or leave. If marriage has occurred, the thing that must be avoided is divorce, even though divorce is part of the law of the existence of unity or marriage itself . Divorce is done to release a marriage which is considered to be defensible. Comfort and harmony of the household cannot be felt so it is impossible to continue the marriage. Divorce is a way out of family problems that cannot be resolved.

Divorce is regulated in articles 38 through article 41 of Law No. 1 of 1974 and described in articles 14 to 36 of Government Regulation No. 9 of 1975 concerning the implementation of Law No. 1 of 1974 concerning marriage (hereinafter abbreviated as PP No. 9 of 1975), includes: first, "divorce divorce", namely divorce submitted for divorce application by and at the husband's initiative to the Religious Court, which is considered to occur and applies along with all legal consequences since when the divorce was declared (pledged) in front of the Religious Court. Second, "divorce", namely divorce filed by the divorce lawsuit and at the initiative of the wife to the Religious Court, which is considered to occur and applies along with all legal consequences since the fall of the decision of the Religious Courts that have permanent legal force.

Islam allows divorce, but this does not mean that Islam likes divorce in a marriage, but Islam still views it as something that is contrary to the principles of Islamic law. However divorce is something that is disliked by Allah SWT, as has been explained in the hadith of the Prophet which means "From Ibnu Umar ra.a. he said, Rosululloh SAW said: "Something that is lawful, but God hates it is divorce". (H.R. Abu Dawud. Ibn Majah) . 
The divorce outside the court in question is a divorce that has fulfilled all the terms and conditions of divorce stipulated in Islamic law, but without official stipulation in the authorized institution as stipulated in the legislation. Divorce outside the court because it is not recognized by the state, even though it has been valid according to Islamic law, of course will cause legal problems, especially if later each of them marries another person.

The two largest Islamic organizations in Indonesia have different views about the legitimacy of divorce outside the court. Nsul Masail NU in the 28th Decree of the Nahdlatul Ulamaa Conference held at the Al-Munawir Krapyak Islamic Boarding School in Yogyakarta on 26-29 Rabiul Akhir 1410 H./26-28 November 1989 AD gave a legal decision that talak was the husband's prerogative can be dropped anytime and anywhere even without reason. Therefore, if the husband has not dropped the divorce outside the Religious Court, then the divorce that was dropped before the Religious Judge is calculated as the first divorce and since then the 'iddah' has also been calculated. If the husband has dropped divorce outside the Religious Court, then the divorce that was dropped before the Religious Judge is the second divorce and so on if it is still in time 'iddah raj'iyyah. While the Majlis Tarjih Muhammadiyah in his fatwa that was tried on Friday, 8 Jumadil Ula 1428 H / 25 May 2007 M gave a ruling that divorce must be carried out through a court hearing, divorce divorce was carried out by the husband pledging his divorce in front of a court hearing and divorce the suit was decided by the judge. Divorce conducted outside the court is declared invalid.

Therefore, the Indonesian Ulema Council as an organization founded and composed of various Islamic organizations in Indonesia can be a bridge to find a middle ground as a way out in solving these problems. And finally in the Ijtima Ulama of the 4th Indonesian Ulema Council (MUI) Fatwa Commission at the Cipasung Islamic Boarding School, Tasikmalaya, West Java, which took place from June 29 to July 2, 2012, regarding the legality of divorce outside the court as well discussed.

The legitimacy of off-court divorce is a fierce discussion on the Ijtima Ulama Commission B-1 Fatwa Commission of the Indonesian 4th Ulama Council (MUI) in the Cipasung Islamic Boarding School, Tasikmalaya, West Java that runs from June 29 to date July 2, 2012. Various opinions were conveyed by the participants. To find a meeting point the participants agreed to make the team formulate this issue.

The results of the Commission B-1 Session which discussed the issue of Contemporary Jurisprudence (Masail Fiqhiyyah Mu'ashirah), decided that Talak outside the legal court was valid provided that there was a reason for syar'i whose truth could be proven in court. Iddah talak is counted since the husband dropped divorce. For the benefit of benefit and guaranteeing legal certainty, divorce outside the court must be reported (ikhbar) to the religious court.

The fatwa of the MUI from Ijtima 'Ulema of the 4th Indonesian Fatwa Commission in 2012 decided:

1. Divorce outside the legal court is valid provided there is a reason for syar'i whose truth can be proven in court.

2. Idakah is calculated from the time the husband drops the divorce.

3. For the benefit of the benefit and guarantee of legal certainty, divorce outside the court must be reported (ikhbar) to the religious court.

Based on the description above, there is a difference between divorce outside the court between Islamic law as a reference in positive law about Talak in Indonesia with the Islamic law adopted by the 
largest Islamic organizations in Indonesia, namely the Nahdlatul Ulama and the Indonesian Ulema Council which is followed by the majority of Muslims in Indonesia.

This has led to the dualism of the law regarding divorce in Indonesia, both of which continue to run and at certain times can cause legal problems, especially legal aspects relating to the post-divorce event, including regarding marriage assets. If the divorce is done under the hand, it can certainly cause legal problems. Although the positive law does not recognize talak outside the court, but the belief and obedience of the Muslims, especially from the Nahdlatul Ulama to the opinions of scholars who still adhere to the classical Fiqh book, coupled with the results of the Ijtima 'Indonesian Ulema Council, will certainly cause problems. Religious aspects in marriage law, which include the law of divorce are not easy things to solve. And finally, the legal objective to solve the problem of divorce in the community fairly which can be accepted by the community and the ulama is not achieved.

\section{Formulation of The Problem}

Based on the background above, the formulation of the problem in this paper is as follows: How are the problems arising from divorce outside the court considered invalid?

\section{Research Methods}

The research method that I use in this study is normative juridical. Normative juridical research is research carried out or aimed at written regulations and other legal materials which are secondary data in libraries and other legal journals.

\section{Research Results and Discussion}

Issues of Divorce Outside the Religious Courts

In general the community knows the term divorce and divorce. Divorced is the breakup of marriage because of separation or divorce, while divorce is a breakup of marriage because one husband or wife dies. In Article 38 UUP mentioned Marriage can break up because: a. Death, b. Divorce, c. For Court Decisions.

In Islam, marriage is worship, because the validity of a marriage must also be based on Islamic law, namely fiqh munakahat. In the fiqh munakahat, in addition to regulating marriage, it is also regulated about the end of the marriage relationship, which is about the problem of divorce and related matters such as the period of marriage and referral.

According to UUP, the validity of a marriage is based on the provisions of religion, as stipulated in Article 2 paragraph (1) which reads, "Marriage is legal if carried out according to the laws of each religion and its beliefs". So that in the national marriage law the term marriage under the hand is known, which is a marriage carried out secarah according to religious law but not recorded in accordance with the applicable laws and regulations. With regard to the marriage, it can be legally registered in order to obtain legal certainty and protection from the state through the process of marriage marriage in the Religious Court. 
However in the case of Divorce, the state takes a different position, where in the divorce law, the validity of a divorce is dependent on the Court, as stipulated in article 39 paragraph (1) which reads: Divorce can only be carried out before a Court of Justice after the Court concerned and did not succeed in reconciling both parties. So that the National Marriage Law does not recognize the name under divorce or Divorce outside the Court. Therefore Divorce Outside the Court is considered to have never existed and is illegal, even though it has been valid according to Islamic religious law. And even this rule is followed by Compilation of Islamic Law as a guideline for Indonesian Muslims in implementing Islamic law relating to national law such as Marriage, Waqf, inheritance, and i Economics.

Actually the rule is not right. Legal actions that are born and legitimate by religious law, should also be ended by the rules of the religious law. Or in other words if marriage is legal according to the religion, divorce is also valid if carried out according to the religious law. Whereas the function of the Court is to ascertain whether or not the divorce is carried out according to the religious law.

So if analogized if in marriage law, marriage under the hands can be registered / registered officially after going through the process of marriage isbat to ensure whether the marriage is carried out in accordance with religious law. Then Divorce Outside the Court should be able to be registered / registered officially after going through the Isbat trial process to check whether the divorce is carried out in accordance with religious law or not.

Although the Marriage Law which was intended to unify marital law in Indonesia has been in force since 1974 and the Compilation of Islamic Law which aims to unite Islamic law by making a sort of codification that becomes a reference for judges in religious courts has been in effect since 1992 in which divorce law stipulates that divorce must be carried out in front of a religious court, it turns out that until now, there are still a lot of talak conducted outside the religious court.

Divorce outside the court has caused problems that seem unable to be resolved. On the one hand, Muslims are taught in Islamic fiqh that talak is the right of a husband, where if a husband is mentally Islamic even without witnesses, then his divorce falls, while the marriage law in Indonesia, including the Islamic ummah is specifically regulated in the Compilation of Islamic Law, determine that divorce can only be carried out before a religious court after going through a trial.

This situation continues to apply to this day, both based on official marriages at the Office of Religious Affairs, as well as on marriages under the hands that are carried out in a religious manner. For an official marriage in KUA, someone who wants to remarry on the grounds that he is divorced must show a divorce certificate issued by the KUA and divorce based on the verdict of the religious court, while the previous marriage is under the hands, then the marriage certificate must be submitted. talak in the Religious Court.

However, sometimes a person who, because of his religious beliefs, has divorced under his hands does not inaugurate it through a Religious court, then marries under his hands, giving rise to legal problems, especially in child-born marriages which will certainly cause problems regarding the legal status of the child. And specifically for women who are remarried under the hands of an official divorce, then there is no way to formalize the status of their children as legitimate children.

The results of the author's interview with Drs. H. Abdul Hakim, MHI, former Chairperson of the Lubuk Basung Religious Court from 2006-2010, it was revealed that cases like the above often occur in the community. In the Application for Marriage Issues, Even though the applicants and witnesses stated that the wife had divorced from her first husband under the hands through a divorce process outside the court by strengthening the stamped divorce statement as written evidence, the judge refused to grant her 
marriage certificate on the grounds that under Article 38 UUP and Article $141 \mathrm{KHI}$, divorce must be carried out before the court.

If you face a case like this, according to Drs. H. Abdul Hakim, MHI, the Judge advised the wife to file a divorce claim against her first husband, then after the divorce decision and after passing the iddah period, the wife could form an official marriage with her second husband at KUA. But what remains a problem that cannot be resolved is the status of children born in marriage under his hands who are legally status as children born outside of marriage and this will result in differences in status with children born after official marriage, especially in relation to guardianship and inheritance rights. It will be different if the husband is still not officially divorced, where if his first wife gives permission, then the marriage certificate can be granted and then divorce with his first wife can be inaugurated before the court.

In general the problems arising from divorce outside the court are:

1. Regarding when the fall of divorce and the end of the iddah period.

2. Regarding triple divorce.

3. Regarding the validity of the status of children born after the fall of divorce

4. Regarding the validity of the second marriage and the status of the child he was born with.

These problems seem to continue to be allowed by the state to continue prolonged without a solution that can bridge the differences. Even the compilation of Islamic law was born through Presidential Instruction No. 1 of 1991 which regulates Islamic law in Indonesia cannot resolve this. The two laws continue to run and continue to live in the community and problems that arise are left without a solution.

Religious Court Judges who should be able to provide a way out with their authority in the formation of new law through legal discovery that can be stated in decisions which if followed can become jurisprudence as if they were bound by UUP and KHI rules, one of which is to make divorce difficult. Is it difficult to divorce society to continue to be left in legal uncertainty that can make legal chaos in the community?

Divorce issues outside the court, one day will become a time bomb in the community, which when exploding can cause legal chaos that has a major impact on the general public and the Indonesian Muslims in particular. Especially with the growing national population system that requires the existence of a marriage certificate for family registration, it will lead to a large number of illegal family families who have children outside of marriage due to a national marriage law system that is not conducive to Islamic marriage law regulated in Islamic fiqh books.

1) When the Fall of the Divorce and the end of the iddah period

Regarding when the fall of divorce and the end of the iddah period are related to the legitimacy of divorce, based on Islamic Fiqh law, according to Syech Muhammad Salih al-Utsyaimin, divorce falls and is validly valid since spoken by the husband or when written by the husband. Regarding witnesses, the ulama's ijma does not require it, so that immediately after it is said, the divorce is valid .

During the iddah period, both can reconcile as husband and wife, both with a clear statement from the husband with acceptance by the wife or by doing jimak (intercourse) between husband and wife which indicates that they have referred. But if until the end of the iddah period, both of them do not make reconciliation, then both of them have divorced and if they want to return, then they must do a marriage. 
UUP and KHI require that divorce must be with a court ruling, so that even if one thousand say a husband's divorce to a wife, then divorce has not fallen. According to UUP and KHI, divorce must be made before the judge after obtaining permission from the court Religion and divorce and the iddah period began after the recitation of the pledge of divorce by the husband before the judge. So that something that is haram (zina) according to Islamic fiqh can be halal according to UUP and KHI as well as vice versa something that is lawful according to Islamic fiqh, becomes something that is unlawful according to UUP and KHI. If this happens, who bears the sin ...?

\section{2) When triple divorce falls.}

Based on fiqh, triple divorce Islam falls after talak is mentioned and occurs three times. Ibn Taymiyyah and his pupil Ibn al-Qayyim argued that divorce three times once was punished illegitimately and considered only one divorce (not three times divorce). This opinion is also the opinion of most tabi'in.

Unlike UUP and KHI, a husband may refer to a thousand times with his ex-wife, even if there is no period as long as he has not officially divorced in court. So that it was common in the divorce trial, the wife postulated that her husband had thrown herself three times until according to the fiqh three divorces had fallen, but the judge only decided on one divorce.

3) Status of children born and fertilized after the fall of divorce.

a) Refer after passing the iddah period.

This can occur when the couple reconciles after the mid-term period without remarriage on the grounds that the divorce is invalid because it was not conducted through a court hearing.

By state law, there has not been a divorce, but according to Islamic law, divorce has occurred and the period of iddah has been passed, so to return must be with remarriage. If not done, then intercourse between the two including adultery and children born are children born from adultery.

Someone who has a religious awareness or strong faith, must be more afraid of religious law than state law. Moreover, those relating to worship and sin to Allah SWT. Where adultery in Islam includes major sins.

b) Refer after triple divorce.

To be able to refer for a husband A wife who is divorced after triple divorce, in Islamic Law is required that the wife must have been married and divorced from another man. This is so that the husband does not easily say the word divorce to his wife.

It often happens, that a husband has divorced his wife up to 3 times outside the court, so that by law Islamic jurisprudence has fallen three divorces. But because he wanted to return to referral, her husband applied for a divorce to a religious court. In the trial, the husband and wife claimed to have divorced three times, until three divorces had fallen according to Islamic Fiqh law. But because the divorce trial between them had only happened once and the UUP only passed a divorce in front of the court, the Judge only dropped one divorce. 
Furthermore, because the verdict is one divorce, the husband and wife can immediately refer after the recitation of the divorce vows by the husband before the court without the wife having to marry another man.

Based on the illustration above, with the difference between Islamic Fiqh and KHI, it is easy for people to play with religious law and state law by utilizing existing legal loopholes.

Because the judge decided so, while the judge knew how true Islamic Islamic jurisprudence was, then who would bear the sin of adultery and the status of the child born for it.

Indeed, the sins of those who forbid that are lawful by Allah and justify those which are forbidden by Allah, even though he knows them. Kaidah Shar'i said: "Whoever justifies the forbidden, then he has disbelieved. And whoever forbids the lawful then he has disbelieved".

4) The validity of the second marriage and the status of the child he was born with.

The validity of the second marriage by a wife who is accused outside the court always raises problems after the birth of a child and is required to formalize his marriage with the marriage isbat process.

Generally, a wife who is charged outside the court if she wants to remarry always takes shortcuts through marriage under the hands or siri marriage, because it is impossible to do an official marriage at the KUA because her marriage is still recorded as a wife and has not divorced or has a divorce certificate. Moreover, no one told him the losses he could experience due to the siri marriage.

If viewed from UUP and KHI, for whatever reason, siri marriage performed by a woman who has been accused of being outside court is very detrimental. The marriage, even though it has been legally valid cannot be ratified by the court through marriage certificate, and the status of the child he was born into is a child born outside the court.

\section{Conclussion}

Many problems arise due to divorce outside the court which are not recognized by the Marriage Act, whereas according to Islamic law the ulama and the community believe is legal. These problems include when the fall of divorce and the end of the period of iddah, concerning triple divorce, concerning the validity of the status of children born after the fall of divorce and the validity of the second marriage and the status of children born can damage the religion and descendants of the Islamic ummah in Indonesia. If marriage is legal if it is done according to the religion, divorce should also be valid if it is carried out according to the religious law.

Factor factors that cause divorce outside the court include economic factors (poverty), juridical factors (dualism of divorce law and still many unregistered marriages, sociological factors (community obedience to scholars) and customs factors. 


\section{References}

Abdul Ghofur Anshori, Hukum Perkawinan Islam (Perspektif Fikih dan Hukum Positif), Yogyakarta: UII Press, 2011

Abdul Aziz Muhammad Azzam, Fiqih Munakahat, Cet.1, Jakarta: Amzah, 2009,.

Ahmad Azhar Basyir, Hukum Perkawinan Islam, Yogyakarta: Fakultas Hukum UII, 1977

Ahmad Rofiq, Hukum Perdata Islam di Indonesia, Jakarta, Rajawali Press, 2013,

As Sayyid Sabiq, Fiqh as Sunnah, Beirut: Dar al Fikr, 1977,

Bambang Sunggono, Metodologi Penelitian Hukum, Rajawali Pres, Jakarta, 2003

Beni Ahmad Saebani, Perkawinan Dalam Hukum Islam Dan UndangUndang, Bandung: Pustaka Setia, 2008

Budi Susilo, Prosedur Gugatan Cerai, Pustaka Yustisia, Yogyakarta, 2008

Hasbullah Bakry, Pedoman Islam di Indonesia, Universitas Indonesia Pers: Jakarta: 1988,.

Kamal Muchtar, Asas-Asas Hukum Islam, PT KaryaUnipress, Jakarta, 1974

M. Anto Mudzar, Fatwa Majelis Ulama Indonesia Dalam Persepektif Hukum Dan Perundang-Undangan, Jakarta: Puslitbang Lektur Dan Khazanah Keagamaan Badan Litbang Dan Diklat Kementrian Agama $\mathrm{Ri}, 2012$

Mohd. Idris Ramulyo, Perkawinan Islam: suatu Analisis Undang-Undang No. 1 Tahun 1974 Dan Kompilasi Hukum Islam, Jakarta: PT. Bumi Aksara, 2004

Muhammad 'Azzah Darwuzah, Al Tafsir Al Hadits Tartib Al Suwar Hasab Al Nuzul, Beirut: Dar Al Gharb Al Islami, 1994,

Muhammad Amin Suma, Hukum Keluarga Islam di Dunia Islam, Jakarta: PT Raja Grafindo Persada, 2004

Muhammad Salam Madku, Peradilan Dalam Islam, Binas Ilmu, Surabaya, 1990,

Muhammad Syaifuddin, dkk, Pluralitas Hukum Perceraian, Tunggal Mandiri Publishing, Malang , 2012,

Salim HS dan Erlies Septiana Nurbani, Penerapan Teori Hukum Pada Penelitian Disertasi Dan Tesis, Rajawali Press, Jakarta, 2014, .

Soeparmono, Hukum Acara Perdata dan Yurisprudensi,Bandung, Mandar Maju, 2005

Sumiyati, Hukum Perkawinan dan Undang-undang, Yogyakarta: Liberty, 1986

Yusuf al Qardawi, Malamih al Mujtama' al Muslim Alladzi Nansyuduhu, Kairo: Maktabat Wahbah, 2001, hlm. 248. 


\section{A. Peraturan Perundang-undangan}

Undang-Undang Dasar Republik Indonesia Tahun 1945.

Undang-Undang Nomor 1 Tahun 1974 tentang Perkawinan.

Undang-Undang Nomor 48 Tahun 2009 tentang Kekuasaan Kehakiman.

Peraturan Pemerintah Nomor 9 tahun 1975 tentang Pelaksanaan Undang-Undang Nomor 1 Tahun 1974

Tentang Perkawinan

Instruksi Presiden Nomor 1 Tahun 1991 Tentang Kompilasi Hukum Islam

\section{B. Website}

Nafilah Abdullah, Menyoal Kembali Perkawinan dibawah Tangan ( Nikah Sirri) di Indonesia, http://ejournal.uin-suka.ac.id/pusat/MUSAWA/article/ download/840/780

Bagian ketiga, Keputusan Ijtima’ Komisi Fatwa Ulama se Indonesia, http://muijatim.org/wpcontent/uploads/2016/09/Ijtima-Ulama-Lampiran1_2009.pdf

Nafi Mubarak, Sejarah Hukum Perkawinan Islam di Indonesia, http://jurnalfsh. uinsby.ac.id/index.php/ alhukuma/article/view/246/236

Zudan Arif Fakrulloh, Hakim Sosiologi, Hakim Masa Depan, http://www.indomedia.com/ bernas/9708/26/UTAMA/26opi.htm,

Teguh Alexander, Kriteria Putusan Hakim yang Ideal, http://teguhlmexander.blogspot.co.id/ 2008/12/kriteriaputusan-hakim-yang-ideal.html

Kamus Besar Bahasa Indonesia, https://kbbi.web.id/poligami

Putusan MK Nomor. 12/PUU-V/2007 pengujian UU Perkawinan, http://www.mahkamahkonstitusi.go.id/public/content/persidangan/putusan/putusan_sidang_Putusan1 2PUUV2007ttgPerkawinantg13Oktober2007.pdf

Shidarta, Putusan Hakim dengan Rasa Hayat Historis, http://www.Dr.Shidarta, SH,M.,Hum.htm,

Febrizal Lubis, Ambiguitas Sanksi Pidana Terhadap pelaku Poligami Illegal, https://badilag.mahkamahagung.go.id/artikel/publikasi/artikel/ambiguitas-saksi-pidana-terhadappelaku-poligami-ilegal-oleh-febrizal-lubis-sag-sh-15,

Website Sudut Hukum Portal Hukum Indonesia. teori Penjatuhan Putusan, http://www.suduthukum.com/2016/10/teori-penjatuhan-putusan.html

Website Sudut Hukum Portal Hukum Indonesia. teori Keseimbangan, http://www.suduthukum.com/2016/10/teori-keseimbangan.html

Website Sudut Hukum Portal Hukum Indonesia. teori Pengekatan Seni dan Intuisi, http://www.suduthukum.com/2016/10/teori-pendekatan-seni-dan-intuisi.html 
Website Sudut Hukum Portal Hukum Indonesia. teori Pendekatan Pengalaman, http://www.suduthukum.com/2016/10/teori-pendekatan-pengalaman.html

Website Sudut Hukum Portal Hukum Indonesia. teori Pendekatan Keilmuan, http://www.suduthukum.com/2016/10/teori-pendekatan-keilmuan.html

Website Sudut Hukum Portal Hukum Indonesia. teori Rasio Decidendi, http://www.suduthukum.com/2016/10/teori-ratio-decidendi.html

Blog Miftahul Huda, Rasio decidendi, http://www.miftakhulhuda.com/2011/03 /ratio-decidendi.html

Website Sudut Hukum Portal Hukum Indonesia. teori Kebijaksanaan http://www.suduthukum.com/2016/10/teori-kebijaksanaan.html

Website Detik News, Fatwa MUI : Nikah Siri Sah, https://news.detik.com/berita/605475/fatwa-mui-nikahsiri-sah

Blog Fuad Nazar. https://fuadnasar.wordpress.com/2017/04/01/hukum-islam-dalam-negara-pancasilamengenang-prof-dr-h-busthanul-arifin-sh/,

Blog Mutiara Zuhud, https://mutiarazuhud.wordpress.com/tag/tidak-akan-bersepakat-dalam-kesesatan/,

Website Seputar Pengetahuan, https://www.seputarpengetahuan.co.id/2017/08/13-pengertian-yurisprudensimenurut-para-ahli.html

\section{Copyrights}

Copyright for this article is retained by the author(s), with first publication rights granted to the journal.

This is an open-access article distributed under the terms and conditions of the Creative Commons Attribution license (http://creativecommons.org/licenses/by/4.0/). 